IN January 1972 a study group of psychologists and ethologists met in London to discuss the growth of competence, under the aegis of the Developmiental Sciences Trust and the Ciba Foundation. This book represents the fruits of their discussion; it comprises 16 papers presented either at the symposium or commissioned during its aftermath for inclusion in the published proceedings.

Most of the original papers have been revised in the light of comments made at the conference, and the editors have written introductory and concluding chapters. It is unusual, however, for such manoeuvres to transform a collection of individual papers on a common theme into a plausible book in which an identifiable argument is developed, and it must be said that The Growth of Competence has several of the characteristic flaws of the standard conference book. The most serious of these may be anticipated: the word 'competence' has such wide vernacular use that it comes as no surprise to discover between the book's covers almost as many definitions of its central concept as there are contributors. And even though this state of affairs may arise from the nature of the concept rather than from lexicographical laxness on the part of the authors, its

\section{Competence in many forms}

\section{John N. Nicholson}

The Growth of Corrpetence. (Proceedings of a DST Study Group.) Edited by Kevin Connolly and Jerome Bruner. Pp. xii + 327. (Academic: London and New York, September 1974.) £6.80; $\$ 17.50$.

effect on the book may be imagined. There are, moreover, a number of chapters which can with charity be described as lightweight. They neither iriclude material interesting in its own right nor contribute to the argument which, in spite of the handicap mentioned above, is developed in the book; they are presumably included in deference to the book's function as a document of record.

These shortcomings are particularly regrettable in view of the book's praiseworthy intentions and the admirable quality of some of the contributions. It sets out to describe competence; to place it in an evolutionary context (a wide-ranging chapter by Bruner); to exemplify its development in a number of areas, including infants' relationships with their mothers and their peers, skills (a detailed description of Elliott and Connolly's pioneering analysis of manual skills in normal and cerebral palsied children), language acquisition and personality; and to point out the practical applications of the experiments discussed and theoretical issues raised.

The book's central argument is carried forward by those contributors who follow Bruner in likening the growth of competence to the development of skills, which he regards as an hierarchically organised repertoire of sub-routines. This analogy is pushed furthest by Susan Carey in a provocative chapter on the development of cognitive competence, based on her penetrating reanalysis of the conservation problem. But in the end the book cannot escape the limitations of its genre. Most of the experimental work has been described elsewhere; it is unlikely therefore to become mandatory reading amongst developmental psychologists. Educationalists may welcome the discussion of the efficacy of schools as socialising agents in contemporary society, but they will find little cheer in the editors' pessimistic view of the contribution psychologists have thus far been able to make towards the solution of such problems.

THE subject is fascinating. How is it archive at the Center for Advanced that the principal area of technological rivalry between the two super-powers could within two years become the main field of cooperation in advanced projects? What shifts in foreign policy, in the scientific climate, even in personalities, mediated so radical a 'thaw'? Alas, one is not going to get more than a few hints from this book.

Was the untimely death of Dr Hugh Dryden, NASA's chief negotiator during the difficult early 1960 s a significant setback? Did the 1964 Committee on Space Research (COSPAR) agreement on planetary contamination standards mark the first visible breakthrough of reason over rivalry (as was then widely reported)? There is no assessment of the first point and the second is not mentioned.

\section{Detente in orbit} Angela Croome

U.S.-Soviet Cooperation in Space. By Dodd L. Harvey and Linda C. Ciccoritti. Pp. 350. (University of Miami: Florida, 1974.) \$8.95, paper; $\$ 12.95$, boards.

foreword by the United States Ambassador to Moscow in the mid-1960s, Foy D. Kohler, who is now luminary of

Disappointment with the book at first prompts the judgement that it is quite irrelevant. It is not; it is just biased. The book has apparently been developed through a series of studies by a team of authors drawing on a privileged
International Studies of the University of Miami (CIAS). It presents a digest of official, documentary evidence and American reportage (which are given equal validity) within the matrix of the authors' own commentary.

The whole thing is set rolling in a predetermined direction with a 28-page

allegiance reduces any conviction and the material adduced suggests that there has been some careful selection to support his thesis. Nor does he acknowledge the equally overriding influence of American political postures on the turn of events during the 15year period leading up to the 1972 Nixon-Brezhnev Agreement (the space cooperation programme was, significantly, a part of the overall detente agreement)

It is useful to have chapter and verse of the Dean Rusk papers (1962) which concluded that space had. no military value for the United States and which suggested that the Soviet Union should appreciate this before adopting counter measures to a nonexistent threat. That was a turning point.

The volume's 100-page bibliography CIAS. He discounts any possibility of would be invaluable if it could be conan independent role or influence from sulted independently of the text. As it Soviet scientists. He sees the entire is, this 'analysis' is journalistic in pattern of cooperation as determined approach but does not have the conby Soviet political pressures. He may venience of having been written by well be right but his own professional journalists. 